\title{
IAMJ
}

INTERNATIONAL

AYURVEDIC

MEDICAL JOURNAL

\section{VIRECHEN, LEKHANA BASTI AND ORAL THERAPY AN AYURVEDIC PROTOCOL FOR MANAGEMENT OF UTERINE FIBROID IN AN INFERTILE WOMAN - A CASE REPORT}

\author{
Balat Gauravkumar R.*1, L. P. Dei ${ }^{2}$ \\ ${ }^{1} \mathrm{Ph} . \mathrm{D}$ Scholar, Department of Prasooti Tantra and Stree Roga, \\ ${ }^{2}$ Professor and Head, Dept. of Prasooti Tantra and Stree Roga, and Dean \\ IPGT \& RA, Gujarat Ayurved University, Jamnagar, Gujarat, India 361008
}

Corresponding Author: balatgaurav@gmail.com

https://doi.org/10.46607/iamj3608112020

(Published online: November 2020)

Open Access

(C) International Ayurvedic Medical Journal, India 2020

Article Received: 17/10/2020 - Peer Reviewed: 06/11/2020 - Accepted for Publication: 08/11/2020

D) Check for updates

\begin{abstract}
Background: Infertility is inability to become pregnant for a sexually active couples after one year without using any contraceptives. It causes great distress to many couples. The benign tumor that originate in the uterus it is called a uterine fibroid. The growths are typically benign, or noncancerous. The cause of fibroids is unknown and there are many ways will affect the fertility of woman. Aim \& Objective: To understand the disease according to Ayurvedic principles \& to evaluate the role of a safer and cost-effective Ayurvedic treatment modality in uterine fibroid in infertile women. Materials and Methods: A clinical case study of uterine fibroid. Patient age 25 years with 2 years active marital life attending the O.P.D. of P.T.S.R. of IPGT \& RA, Jamnagar. Patient was treated with Virechana Karma (Purgation) with Trivrut Avaleha with Thripala Kwatha (Decoction), Lekhana Basti (Enema) with Lekhaneya Maha Kashaya for 15 days, Varunadi Kwath (Decoction) 50ml for 8 weeks morning and evening after meal Results: There is great reduction to the size of the fibroid and the woman became pregnant and delivered a healthy baby. Conclusion: Hence it has been concluded that this Ayurvedic protocol useful the management of uterine fibroid in infertile woman.
\end{abstract}

Keywords: Uterine fibroid, infertility, Virechana. Lekhana Basti

\section{INTRODUCTION}

Fibroids are the Commonest Benign tumor of the Uterus and also the commonest benign solid tumor among female and most of them (50\%) remain asymptomatic. The incidence of symptomatic fibroid 
in hospital outpatient is about 3\%. These are the most common in nulliparous or in patients having one child infertility i.e. secondary infertility. The prevalence is highest between $35-45$ years age group. ${ }^{1}$ Infertility is inability to conceive after 1year of regular unprotected coitus. ${ }^{2}$ There are so many causes for infertility including factors of both male and female. There are several ways the uterine fibroids will affect the fertility of woman. Uterine fibroids changes the shape of the uterus, fallopian tubes can be blocked, impact the endometrial lining, the blood flow to the uterine cavity can be effected, and all these things will decrease the ability of implantation of embryo into the uterine wall. ${ }^{3}$ The size and location of fibroids determines whether it affect fertility. Small fibroids directly do not cause infertility. But large fibroids, size more than $5 \mathrm{~cm}$ and submucous type fibroid can cause infertility. Submucous fibroids may prevent the proper implantation of embryo there by result either infertility or miscarriage. Fibroids during pregnancy can change baby's position in the uterus. This will increase the risk of Miscarriage, Preterm labour, and Cesarean section. They also create problems such as Placental abruption, intrauterine growth retardation. ${ }^{4}$ Due to defective implantation of the placenta, poorly developed endometrium, reduced space for the growing fetus and placenta. ${ }^{5} \mathrm{~A}$ woman's ability to get pregnant can be affected by age. According to Ayurveda Ritu, Kshetra, Ambu, \& Beeja are the four essential elements for proper conception. Impairment to any of these factors leads to Vandhytva (Infertility) or pregnancy failure. Charak has mentioned Arbuda (tumor) in ChikitsaSthana and described Arbuda as Shophavisesha (one of the forms of Shotha). ${ }^{6}$ This clearly indicates that basically aetiopathogenesis, clinical features and treatment of tumours of reproductive system are identical to the tumours of any other body part; however, few clinical features present due to specific location of disease has to be investigated. Uterine fibroids do not have definite medical treatment in the modern gynaecological practices other than surgery, available treatment protocol in modern are hormonal therapy, hysterectomy, myomectomy, myolysis, endometrial ablation and uterine artery embolization with their own limitations and complications. Therefore, she consulted for the Ayurvedic medication.

\section{Case Report:}

Presenting Complaints: a 25-year-old female who was a housewife came to OPD of Stree Roga department of IPGT \& RA, Jamnagar on 4 July 2019, having the complaints of weight gain and failure to conceive since 2 years of active married life.

History of Present Illness: she narrated her history of presenting complaints as follows, lower abdomen pain since last 1 year. She had regular cycles (i.e. 2 3 days flow/28-30 days cycle/ 2-3 pad) associated with spasmodic dysmenorrhea [Udavartini Yoni Vyapad]. She had taken allopathic treatment for the complaints of infertility and painful menstruation for 2 years. But still there was not any considerable improvement, so the patient came to take ayurvedic treatment. During this treatment all basic investigations of both husband and wife were done during the evaluation of infertility, sonography revealed an anterior wall subserosal single fibroid $(3.8 \times 3.5 \times 2.9) \mathrm{cm}$ with $15 \mathrm{cc}$ volume and $40 \mathrm{cc}$ uterine volume and both ovaries were bulky with multiple small follicles.

Family History: mother was hypertensive

\section{Personal history:}

Diet - Vegetarian, Appetite - Good, Bowel - Regular, Micturition - Normal, Sleep - Normal, Exercise - Not at all, Sexual life - 5-6time/week

Husband factor: husband - private job. Semen analysis was normal, and he had no erectile dysfunction etc.

\section{General examination:}

\section{Female partner}

Per abdomen, $(\mathrm{P} / \mathrm{V})$ per vaginal and $(\mathrm{P} / \mathrm{S})$ per speculum examinations were normal.

\section{General Examination}

Body weight $-93 \mathrm{~kg}$, Height $-152.5 \mathrm{~cm}$, BMI - 40 $\mathrm{Kg} / \mathrm{m}^{2}$, Pulse rate $-84 / \mathrm{min}$, BP $-120 / 80 \mathrm{mmHg}$

Investigations: the blood values of the patient before treatment (B.T.) and after treatment (A.T.) are as under i.e. Table 1.

Table 1: Hematological \& Urine investigation.

\begin{tabular}{|l|l|l|l|}
\hline Sample & Particulars & Obtain Value & \\
\hline & & B.T. & A.T. \\
\hline Blood & Hb gm\% & 12.4 gms $\%$ & 12.4 gms $\%$ \\
\hline
\end{tabular}




\begin{tabular}{|l|l|l|l|}
\hline \multirow{5}{*}{} & TC/ cumm & $7700 /$ cumm & $6900 / \mathrm{cumm}$ \\
\hline & DC $-\mathrm{N} \%$ & $60 \%$ & $62 \%$ \\
\hline & $\mathrm{B} \%$ & $00 \%$ & $00 \%$ \\
\hline & $\mathrm{E} \%$ & $03 \%$ & $02 \%$ \\
\hline & $\mathrm{L} \%$ & $32 \%$ & $33 \%$ \\
\hline & $\mathrm{M} \%$ & $05 \%$ & $03 \%$ \\
\hline & ESR mm/hr & $26 \mathrm{~mm} / \mathrm{hr}$ & $38 \mathrm{~mm} / \mathrm{hr}$ \\
\hline & PCV $\%$ & $35.8 \%$ & $37.3 \%$ \\
\hline & B. T & $1.40 \mathrm{sec}$ & $1.35 \mathrm{sec}$ \\
\hline & C.T & $3.55 \mathrm{sec}$ & $3.50 \mathrm{sec}$ \\
\hline Urine & Routine & Nill & Nill \\
\hline \multirow{3}{*}{ Blood sugar } & Microscopic & Nill & Nill \\
\hline & Fasting & $86 \mathrm{mg} / \mathrm{dl}$ & $77 \mathrm{mg} / \mathrm{dl}$ \\
\hline & HIV & Negative & Negative \\
\hline & VDRL & Negative & Negative \\
\hline & HBsAg & Negative & Negative \\
\hline
\end{tabular}

The hematological and urine investigation are normal (Table 1)

USG:

1. USG pelvis and H.S.G (Hysterosalphingography) reports were normal

2. Ovulatory study has anovulatory cycles.
Treatment protocol: Patient has been given following treatment for four months after taking the informed written consent.

1st month - Virechana Karma

$2^{\text {nd }}$ month - Lekhana Basti

$3^{\text {rd }}$ and $4^{\text {th }}$ month - Oral therapy

\section{1st Month of Treatment Protocol}

\section{Virechana}

\begin{tabular}{|l|l|l|}
\hline Procedure & Drug and Dose & Duration \\
\hline Deepana \& Pachana & Amapachanavati- 2 tablets/bd / before meal with Lukewarm water & 3 days \\
\hline Snehapana & Goghrita (as per Kostha and Agni) 30ml -150ml empty stomach in morning & $3-7$ days \\
\hline Abayanga \& Swedana & Tila Taila & 3 days \\
\hline Virechana Karma & Trivrut Avaleha $100 \mathrm{gm}$ with Triphala Yavakuta $30 \mathrm{gm}$ & 1 days \\
\hline Samsarjana Karma & Diet (as per KoshthaShuddhi) & $3-7$ days \\
\hline
\end{tabular}

2. Lekhana Basti: Lekhaneya Maha Kashya (Decoction) was used for Lekhana Basti ${ }^{7}$

\begin{tabular}{|l|l|l|}
\hline Procedure & Drug and Dose & Duration \\
\hline Snehana - Abhyanga & Tila Taila (As per required) lower abdomen, lower back and thigh & $15 \mathrm{~min}$ \\
\hline Sekhana Basti & $\begin{array}{l}\text { Nadi sweda by steam lower abdomen, lower back } \\
\text { Lekhaneya Maha kashya - 250ml Kalka Dravya - 10g, Saindhava La- } \\
\text { vana-5g, Madhu (Honey) -30gm, Tila Taila (Sesame oil) - 60ml }\end{array}$ & 15 days \\
\hline
\end{tabular}

In $3^{\text {rd }}$ and $4^{\text {th }}$ Months of Treatment Protocol: Oral Therapy: Varunadi Kwatha ${ }^{8}$

After completion of Basti Karma Oral drug Varunadi Kwatha [Varuna 1 part (16g), Gokshura 1 part (16g), Shunti 1 part (16g), Yavakshara 2g] $50 \mathrm{ml}$ per day/ $\mathrm{BD} / \mathrm{after}$ meal was administration for 8 weeks

\section{Pathyapathya: Pathya}

1. Intercourse during Rutukala.

2. To avoid Mental Stress.
3. To take Simple food.

4. To have more cow's milk.

5. To have Somansya by Good Readings, Yogas and Prayanamas.

\section{RESULTS AND DISCUSSION}

After the complete of 4 month of treatment next period she was reported in the OPD and the severity of lower back pain becomes mild. These subjective criteria were measured by scoring pattern and she took 
USG revealed an anterior wall subserosal single fibroid $(2.8 \times 2.7 \times 2.8) \mathrm{cm}$ with $3.6 \mathrm{cc}$ volume and $11 \mathrm{cc}$ uterine volume it means the size was reduce $(1.8 \times 1.2 \times 0.1)$ with $11.4 \mathrm{cc}$ volume and also $30 \mathrm{cc}$ uterine volume respectively. (Table 2) After 4 month was advised to consume the same oral medicines Varunadi Kwath and directed to consume Churna combination of Bala + Shatavari + Shatpushpa + Guduchi every month from the 5th day of periods to 18th day. After 6 months reported that she is not having periods on the date. She was directed to do UPT and the result was positive. The pregnancy period was uneventful, and she delivered normally. Arbuda is a Bahu Dosaja vyadhi and Virechana karma is the best for vitiated pitta, and also it has Raktaprasadana karma. It helps to normalise the endocrine function by its purifying action. Lekhana by the Lekhana Basti is the process of scrapping or desiccation of all excess Dosha, Dhatu and Mala. That means the drug which rarefies the protoplasmic contents of the tissue cells and thus gradually clears the system of it disarrange constituents is known as Lekhana. As Garbhashaya Arbuda is a Sanga Pradhan vyadhi Lekhana Karma of Srotas is needed. The main ingredient of this drug is Varuna, Gokshura, Shuntiand Yavakshar which have Tikta Rasa. It is Kapha-Pitta Hara, Sophahara, slightly laxative. So, it can easily clear up the channels or Srota. Yavakshar which have Lekhan, Chedan and Granthihara property. It is well known drug of Gulma Roga.

Table 2:

\begin{tabular}{|l|l|l|}
\hline USG (Trans vaginal / abdominal) & B.T & A.T \\
\hline Single / Multiple & Single & Single \\
\hline Type & Subserous & Subserous \\
\hline Size & $3.8 \times 3.5 \times 2.9 \mathrm{~cm}$ & $2.8 \times 2.7 \times 2.8 \mathrm{~cm}$ \\
\hline Volume & $15 \mathrm{cc}$ & $3.6 \mathrm{cc}$ \\
\hline Location & Anterior wall & Anterior wall \\
\hline Uterine Volume & $40 \mathrm{cc}$ & $11 \mathrm{cc}$ \\
\hline
\end{tabular}

\section{CONCLUSION}

The case study concluded that Virechan, Lekhan basti and Varunadi Kwath very effective in uterine fibroid and also highly effective in promoting the ovulation and helps in achieving conception without any side effects and needed to be study in a greater number of patients. So, it is a promising intervention for future practices of Ayurvedic gynaecologists for managing female infertility due to uterine fibroid.

\section{REFERENCES}

1. Dutta's DC. Textbook of Gynaecology, edited by Konrar. Hiralal, 6th edition, New Central Book Agency Ltd. Kolkata, Page No. 259.

2. Professor Dr. C.S. Dawn \& Dr. Subrata Dawn, C.S. Dawn Textbook of Gynaecology, Contraception and Demography, Dawn Books25B, C.I.T. Road, Entally, Kolkkatta, 14th ed, 2003,pg - 103

3. www.reproductive factors.org.

4. https://Innovativegyn.com

5. D.C.Datta, Editted by Hiralal Konar, DC Dutta's Textbook of Gynecology including Contraception, Jaypee Brothers Medical Publishers (p) LTD, New Delhi, 17th ed. 2016pg. 225
6. Agnivesha, Charaka, Dridhabala, Charaka Samhita, ChikitsaSthana, Shwayathu Chikitsa Adhyaya, 12/74, edited by Vaidya JadavjiTrikamji Acharya, reprint ed. Chowkhambha Orientalia, Varanasi, 2011; p-488.

7. Kashinath SP, Gorakhanatha C, editor. Charaka Samhita of Agnivesha,Shutra Sthana. Reprint edition. Ch. 04/03, Varanasi: Chaukhamba Sanskrit Sansthana; 2014. p. 1067.

8. Srilanka/Ayu/ Pharmacop-eia/228/Vol 2

\section{Source of Support: Nil Conflict of Interest: None Declared}

How to cite this URL: Balat Gauravkumar R.* \& L. P. Dei Virechen, Lekhana Basti And Oral Therapy An Ayurvedic Protocol For Management Of Uterine Fibroid In An Infertile Woman - A Case Report. International Ayurvedic Medical Journal \{online\} 2020 \{cited November, 2020\} Available from:

http://www.iamj.in/posts/images/upload/5178 5181.pdf 